\title{
Una ictericia en tres palabras
}

\author{
A jaundice in three words
}

$\mathrm{E}$ n una antigua publicación del Calvo Mackenna ${ }^{1}$ hemos encontrado esta historia, que se remonta a más de treinta años, sin perder por ello su interés anecdótico: al menos así lo creemos y por ello nos atrevemos a reproducirla, cambiando los nombres de los protagonistas para evitar demandas o represalias.

La misteriosa ictericia de Jimena había tenido desconcertados por meses a todos los médicos del hospital. Dos veces su caso se había presentado en reunión clínica, otra a una cita de expertos, y en la Unidad de Infecciosos era la atracción principal. En el hospital regional de su lugar de origen, dictando una conferencia de hepatitis y ante una pregunta sobre la enfermita, nuestro hepatólogo había salido del paso diciendo:

- Esa sola enferma merecería varias conferencias.

Cierto día el Jefe de Infecciosos, regresando de un largo viaje por la cuenca del Rhin, se sentó en la cama vecina y preguntó:

- ¿Esta niña llegó ayer?

El Jefe de Servicio, profesor titular y hepatólogo famoso, se echó a reír, explicándole que tenía ya una larga historia.

- Bueno, bueno -dice el Jefe de Unidad- pero explíqueme, en tres palabras, qué es lo que tiene.

El profesor sopesó los dos gruesos tomos de la historia clínica, sonrió... y dijo:

- En tres palabras: "no sé nada".

Pero la historia no acaba aquí, pues a la semana siguiente, apenas llegado a dictar unas charlas de genética el eminente médico británico John Chrysler, llevados por nuestra desesperación y esperando un milagro, se nos ocurrió llevarlo al modesto alojamiento de la célebre enfermita, y hacer que la becada de la sala, en edición bilingüe, le contara el caso.
El inglés escuchó con expresión de dolorosa concentración, tratando de entender el discurso en lo formal, que ya era difícil, y en el fondo, que era todavía peor. Terminado el complejo resumen del más que complejo problema, todos los nativos quedamos en silencio, esperando las palabras de Hombre Blanco del Norte como los griegos en Delfos aguardaban la voz del Oráculo. El Profesor Chrysler parecía meditar, mirando al techo, y nada decía, trayéndonos a la mente los famosos versos de Villaespesa aprendidos en el colegio:

¡Parla! -dijo a la estatua dando un grito

e inmóvil se quedó como esperando

que se abriesen las fauces de granito... ${ }^{2}$.

¿Habría entendido el "chilinglés" de la doctora? ¿Y, si era así, arrojarían sus palabras una luz deslumbradora sobre el caso? Poneos en su situación: no era hepatólogo, del discurso no entendió mucho, ni sabía qué se esperaba de él. ¿Cómo habríais vosotros salido del paso? ¡Había que decir algo! Entonces, antes de levantarse, agradecernos y huir en pos de su cicerone, abrió la boca y nos dijo, en tres palabras, su diagnóstico, opinión y epicrisis, mientras señalaba con una mirada amable a la confundida becada:

- Very nice girl.

\section{Referencias bibliográficas}

1.- Our Staff. ¡Esto es para el Calvimacken! The Calvimacken Journal of Infectious Chacharalata. 1982; VIII: 26; 12-3.

2.- Villaespesa F. Moisés. Selección de sonetos. Sopena, Buenos Aires 1942; p. 66.

Walter Ledermann

Hospital Luis Calvo Mackenna. 